\title{
Effects of Residual Stresses on Strength and Crack Resistance in $\mathrm{ZrO}_{2}$ Ceramics with Alumina Coating
}

\author{
LI Haiyan ${ }^{1,2}$, HAO Hongjian ${ }^{1,2}$, TIAN Yuan ${ }^{1,2}$, WANG Changan ${ }^{3}$, BAO Yiwang ${ }^{1,2}$, WAN Detian ${ }^{1,2}$ \\ (1. China Building Material Test \& Certification Group Co., Ltd, Beijing 100024, China; 2. State Key Laboratory of Green \\ Building Materials, China Building Materials Academy, Beijing 100024, China; 3. State Key Laboratory of New Ceramics and \\ Fine Processing, School of Materials Science and Engineering, Tsinghua University, Beijing 100084, China)
}

\begin{abstract}
By covering a thin $\mathrm{Al}_{2} \mathrm{O}_{3}$ coating on $\mathrm{ZrO}_{2}$ substrate, compressive stress caused by the mismatch of thermal expansion coefficients between the coating and substrate was introduced in the surface layer of $\mathrm{Al}_{2} \mathrm{O}_{3}-\mathrm{ZrO}_{2}$ pre-stressed ceramics (marked as $\mathrm{A}_{\mathrm{C}} \mathrm{Z}_{\mathrm{S}}$ pre-stressed ceramics). Vickers indentation test was carried out to check the crack resistance in the surface layer and substrate influenced by the residual stresses. The enhancement of the crack resistance in surface layer results in a high flexural strength and excellent damage tolerance. Both theoretical analysis and experimental results show that the compressive stress and crack resistance in the surface layer increase with the increasing ratio of the cross-sectional area of $\mathrm{ZrO}_{2}$ substrate to $\mathrm{Al}_{2} \mathrm{O}_{3}$ coating. Due to the residual compressive stress

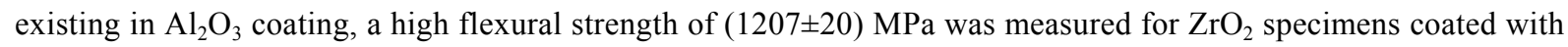
$40 \mu \mathrm{m} \mathrm{Al}{ }_{2} \mathrm{O}_{3}$. The flexural strength is $32 \%$ higher than that of monolithic $\mathrm{ZrO}_{2}$, and about triple of the value of $\mathrm{Al}_{2} \mathrm{O}_{3}$. Meanwhile, compared to $\mathrm{ZrO}_{2}$, the $\mathrm{A}_{\mathrm{C}} \mathrm{Z}_{\mathrm{S}}$ pre-stressed ceramics exhibit superior thermal shock resistance.
\end{abstract}

Key words: $\mathrm{Al}_{2} \mathrm{O}_{3}-\mathrm{ZrO}_{2}$ pre-stressed ceramics; compressive stress; flexural strength; damage tolerance

Zirconia $\left(\mathrm{ZrO}_{2}\right)$ materials have been widely applied in fuel cell, refractory materials, and construction materials due to the prominent mechanical and chemical properties such as high hardness, strength, good wear-resistant, fine oxygen ionic conductivity, excellent heat-insulating and corrosion protective $\mathrm{e}^{[1-3]}$. With the rapid advances of engineering applications, ceramic materials with higher strength and reliability are greatly needed. Therefore, significant improvements are essential to fabricate zirconia components with higher strength and excellent damage tolerance to improve the lifetime and safety of ceramic components. Many efforts including reinforcement strengthening (such as the incorporation of fibers, particles, and whiskers) and transformation toughening were applied to improve the strength and toughness of $\mathrm{ZrO}_{2}{ }^{[4-6]}$. Among them, the way to enhance the strength and damage tolerance of brittle ceramics by introducing residual compressive stress in the surface layer was more attractive because of its remarkable strengthening effect and convenience ${ }^{[7-8]}$. It is well-known that the fracture of ceramics is mainly caused by crack propagation in the surface layer. Thus, the key to improve the strength and damage tolerance of ceramics is to enhance the resistance to crack propagation in the surface ${ }^{[9]}$. By covering a coating with lower coefficient of thermal expansion (CTE) than the substrate, compressive stress generated in the coating layer after sintering. Then the compressive stress hinders the crack extension, thereby improve the strength and damage tolerance of ceramics.

In order to illuminate the strengthening mechanism, it is important to understand the effect of residual stress on crack propagation. As it is well known that indentation deformation strongly links to the crack initiation and crack propagation. For the crack propagation behavior investigation, Vickers indentation proposed by Palmquvist in the late 1950s has been widely used because of its simplicity and efficiency ${ }^{[10]}$. By comparing the growth of crack from the indentations made in unstressed and stressed materials, the effect of residual stress on crack propagation could be studied.

In this work, hot-pressed sintering (HP) was used to fabricate $\mathrm{ZrO}_{2}$ ceramics covered by $\mathrm{Al}_{2} \mathrm{O}_{3}$ coating with

Received date: 2021-07-01; Revised date: 2021-07-30; Published online: 2021-07-31

Foundation item: National Natural Science Foundation of China (52032011); State Key Laboratory of New Ceramic and Fine Processing Tsinghua University (KF 202007) ; Youth Fund of China Building Materials Academy (ZD-16)

Biography: LI Haiyan(1989-), female, PhD. E-mail: lihaiyan@ctc.ac.cn 李海燕(1989-), 女, 博士. E-mail: lihaiyan@ctc.ac.cn

Corresponding author: BAO Yiwang, professor. E-mail: ywbao@ctc.ac.cn; WAN Detian, professor. E-mail: dtwan@ctc.ac.cn 包亦望，教授.E-mail: ywbao@ctc.ac.cn; 万德田，教授.E-mail:dtwan@ctc.ac.cn 
strong interface bonding and high density. For comparison, monolithic $\mathrm{ZrO}_{2}$ ceramics were also prepared by the HP process using the same technical parameters. The effects of different ratios of cross-sectional area of substrate to coating (marked as $S_{\mathrm{s}} / S_{\mathrm{c}}$ ) on residual stresses and the crack resistance were further investigated.

\section{Experimental}

\subsection{Material synthesis}

Commercial zirconia with an average particle size of $D_{50}=220 \mathrm{~nm} \quad\left(3 \% \mathrm{Y}_{2} \mathrm{O}_{3}\right.$ (molar percent), G3Y-0200O, Shangdong Sinocera Functional Materials Co. Ltd., China) and alumina with an average particle size of $D_{50}=220 \mathrm{~nm}$ (SAO-020A-M, Shangdong Sinocera Functional Materials Co. Ltd., China) were used as the raw materials in this research. Alumina powders, deionized water, and dispersant (Isobam104 with a molecular weight of 5500060000 , provided by Kuraray Co., Ltd., Osaka, Japan) were added to produce alumina slurry, and their mass contents were $30 \%, 69.2 \%$, and $0.8 \%$, respectively. The mixture was obtained using a planetary mill (YXQM-1L, MITR, China) for $24 \mathrm{~h}$ in zirconia containers with the ball-to-powder weight ratio of 10:1 and rotational speed of $150 \mathrm{r} / \mathrm{min}$.

To fabricate the $A_{C} Z_{S}$ pre-stressed ceramics by hotpressed sintering, graphite die with a diameter of $50 \mathrm{~mm}$ was uniformly sprayed with the above alumina slurry. And the thickness of the $\mathrm{Al}_{2} \mathrm{O}_{3}$ coating was about $40 \mu \mathrm{m}$. Then zirconia powder was put into the $\mathrm{Al}_{2} \mathrm{O}_{3}$-coated graphite die followed by applying a constant pressure of $10 \mathrm{MPa}$. The specimens were heated up to $1450{ }^{\circ} \mathrm{C}$ at a heating rate of $15{ }^{\circ} \mathrm{C} / \mathrm{min}$, and then a constant pressure of $30 \mathrm{MPa}$ was applied for $60 \mathrm{~min}$. For comparison, a monolithic $\mathrm{ZrO}_{2}$ specimen was prepared by a hot-pressing sintering at $1450{ }^{\circ} \mathrm{C}$ with the pressure of $30 \mathrm{MPa}$ for $60 \mathrm{~min}$. Both the $\mathrm{ZrO}_{2}$ specimens with a dimension of $3 \mathrm{~mm} \times 4 \mathrm{~mm} \times 36 \mathrm{~mm}$ and the $A_{C} Z_{S}$ pre-stressed ceramics with the size of $3.6 \mathrm{~mm} \times 4 \mathrm{~mm} \times 36 \mathrm{~mm}$ were machined (the original thickness of $\mathrm{A}_{\mathrm{C}} \mathrm{Z}_{\mathrm{S}}$ pre-stressed ceramics prepared by hot-pressed sintering was $3.6 \mathrm{~mm}$ ).

\subsection{Characterization}

Morphology of the specimens was observed by using a scanning electron microscope (SEM) (Merlin, Zeiss, Germany). The flexural strength was measured by the three-point bending tests with a span length of $30 \mathrm{~mm}$ and a crosshead speed of $0.5 \mathrm{~mm} / \mathrm{min}$ (according to ISO 14704:2000). The residual strengths were investigated to evaluate the thermal shock resistance after quenching the specimens from different temperatures (200, 250, $300,350,400{ }^{\circ} \mathrm{C}$ ) to $20{ }^{\circ} \mathrm{C}$ water (according to ASTM
C1525-18). The measured value of strength is the average of 5 separate measurements. In order to study the effect of residual stress on crack propagation behavior, the specimens with $\mathrm{Al}_{2} \mathrm{O}_{3}$ coatings of different thicknesses $(40,30,20 \mu \mathrm{m})$ were used, because the residual stresses change with the coating thickness. The Vickers indenter (Tukon2500B, Wilson, America) was used to generate the indentation and indentation cracks under different loadings.

\section{Results and discussion}

The $A_{C} Z_{S}$ pre-stressed ceramics were designed as the schematic diagram for plates in Fig. 1(a). To generate compressive stresses in the surface layer, $\mathrm{Al}_{2} \mathrm{O}_{3}$ was applied as the coating material, because it has a lower coefficient of thermal expansion (CTE) than $\mathrm{ZrO}_{2}$. Due to $\mathrm{CTE}$ difference between $\mathrm{Al}_{2} \mathrm{O}_{3}$ coating and $\mathrm{ZrO}_{2}$ substrate, residual compressive stress was generated in the $\mathrm{Al}_{2} \mathrm{O}_{3}$ coating during the cooling process of the $\mathrm{A}_{\mathrm{C}} \mathrm{Z}_{\mathrm{S}}$ pre-stressed ceramics. The way to fabricate pre-stressed ceramics is also available for any ceramic components of various shapes, including cylinders, tubes and spheres, as illustrated in Fig. 1(a). As for structural ceramics, the interface bonding generates significant impacts on mechanical properties ${ }^{[11]}$. Fine interface bonding manner was investigated from the continuous and tight interface illustrated in Fig. 1(b). The cross-sectional SEM image of the $A_{C} Z_{S}$ pre-stressed ceramics indicates that the thickness of $\mathrm{Al}_{2} \mathrm{O}_{3}$ coating is near $40 \mu \mathrm{m}$ (while the thickness for $\mathrm{ZrO}_{2}$ substrate is $3.6 \mathrm{~mm}$ ). Therefore, by employing HP sintering, $A_{C} Z_{S}$ pre-stressed ceramics with a good interface bond between $\mathrm{Al}_{2} \mathrm{O}_{3}$ coating and $\mathrm{ZrO}_{2}$ substrate can be successfully fabricated.

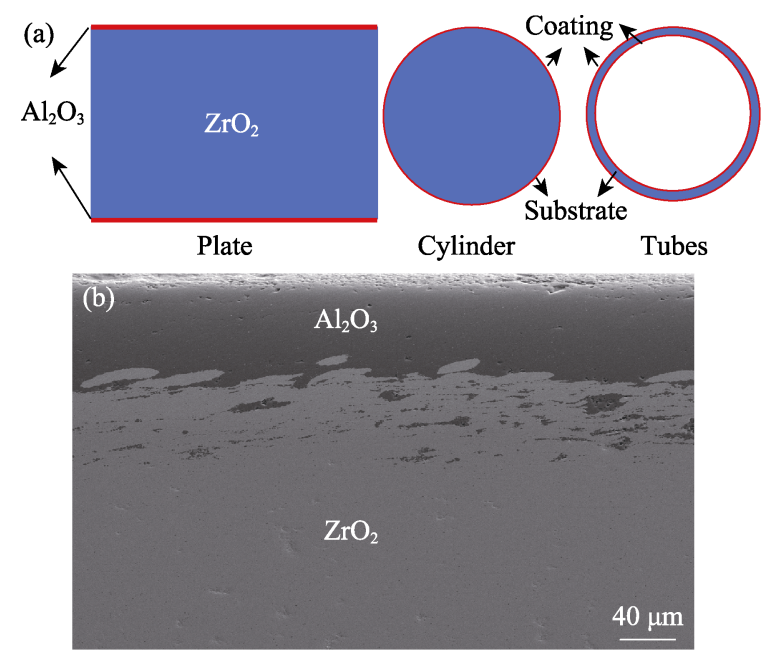

Fig. 1 (a) Schematic diagram of the $A_{C} Z_{S}$ pre-stressed ceramics; (b) SEM image of interface between $\mathrm{ZrO}_{2}$ substrate and $\mathrm{Al}_{2} \mathrm{O}_{3}$ coating 
To investigate the effect of residual stress on crack propagation behavior, Vickers indentation tests were carried out on the $\mathrm{ZrO}_{2}$ ceramics and the $\mathrm{A}_{\mathrm{C}} \mathrm{Z}_{\mathrm{S}}$ pre-stressed ceramics with different ratios of sectional area $\left(S_{\mathrm{s}} / S_{\mathrm{c}}\right.$ is the ratio of substrate to coating in the schematic diagram of plates shown in Fig.1(a)). By comparing the length and expanded direction of crack in Fig. 2(b) and Fig. 3, the indentation diagonal half-length $a$ and the crack length $c$ (illustrated in Fig. 2(a)) can be easily obtained through the observation of indentation morphology. On this basis, the indentation fracture resistance $\left(K_{\mathrm{I}, \text { IFR }}\right)$ used to describe the resistance to indentation cracking ${ }^{[12]}$ can be calculated by Eq. (1) ${ }^{[13]}$. Since the residual stresses are distributed anisotropically, the test conditions for determine the crack resistance does not satisfy all the application requirements of Eq. (1) mentioned in ISO 14627. It is effective to evaluate the crack resistance at different directions in the surface layer and substrate by comparing the measured values of $K_{\mathrm{I} \text {, IFR }}$.

$$
K_{\mathrm{I}, \mathrm{IFR}}=0.000978\left(\frac{E}{H_{\mathrm{V}}}\right)^{0.4}\left(\frac{P}{c^{1.5}}\right)
$$

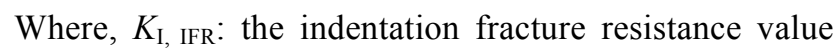
$\left(\mathrm{MPa} \cdot \mathrm{m}^{1 / 2}\right) ; E$ : modulus of elasticity $(\mathrm{GPa}) ; H_{\mathrm{V}}$ : Vickers hardness (GPa);

$$
H_{\mathrm{V}}=0.001854 \frac{P}{(2 a)^{2}}
$$

$P$ : pressing in load $(\mathrm{N}) ; c$ : half of average of crack length $(\mathrm{mm})$; $a$ : half of average of diagonal line length of indentation (mm).

As for the indentation on the polished surface of $\mathrm{ZrO}_{2}$ shown in Fig. 2(b), the cracks propagate outward along the diagonal direction. According to Eq. (1), the calculated $K_{\mathrm{I} \text {, IFR }}$ of $\mathrm{ZrO}_{2}$ ceramics was $9.10 \mathrm{MPa} \cdot \mathrm{m}^{1 / 2}$ (as shown in Table 1). However, different indentation morphology was presented at the $A_{C} Z_{S}$ pre-stressed ceramics with different thicknesses of $\mathrm{Al}_{2} \mathrm{O}_{3}$ coating in Fig. 3. As shown in Fig. 3(a-c), the crack in $\mathrm{Al}_{2} \mathrm{O}_{3}$ coating layer propagates along the direction parallel to the interface, while the crack in $\mathrm{ZrO}_{2}$ substrate propagates along the

(a)

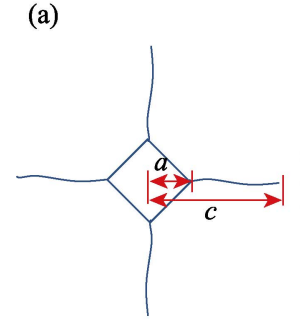

Fig. 2 (a) Typical Vickers indentation of $\mathrm{ZrO}_{2}$ ceramics; (b) Optical photograph of the indentation morphology for $\mathrm{ZrO}_{2}$ ceramics without residual stress
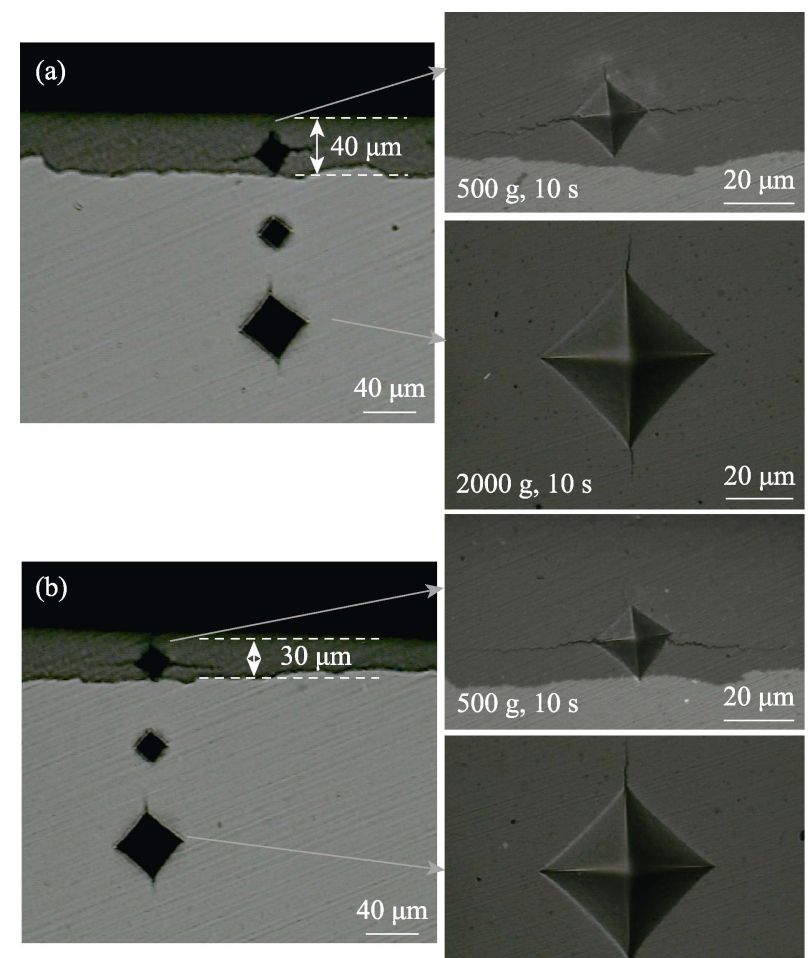

$40 \mu \mathrm{m}$
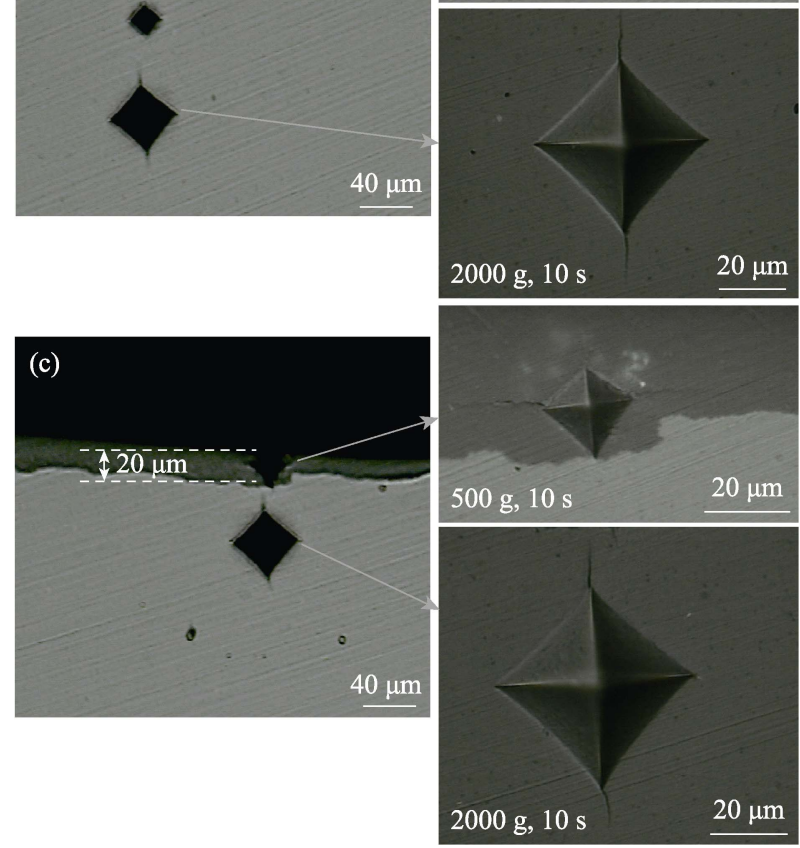

Fig. 3 Optical photographs of the indentation morphologies for $A_{C} Z_{S}$ pre-stressed ceramics with different ratios of the cross-sectional areas, showing the effects of the compressive stresses in the coating and tensile stresses in the substrate

direction perpendicular to the interface. The above phenomenon might be attributed to the compressive stress existed in the $\mathrm{Al}_{2} \mathrm{O}_{3}$ coating, while the tensile stress existed in the $\mathrm{ZrO}_{2}$ substrate, as shown in Fig. 4. And it is well known that the compressive stresses could restrain crack extension and the tensile stress could promote crack initiation and growth ${ }^{[7-8]}$. Therefore, the cracks perpendicular to the interface were restrained in $\mathrm{Al}_{2} \mathrm{O}_{3}$ coating layer, while those were promoted in $\mathrm{ZrO}_{2}$ substrates. Moreover, it was found that the length of crack in $\mathrm{Al}_{2} \mathrm{O}_{3}$ surface layer decreases with the increased value of $S_{\mathrm{s}} / S_{\mathrm{c}}$. The measured $K_{\mathrm{I} \text {, IFR }}$ of $\mathrm{Al}_{2} \mathrm{O}_{3}$ coatings and $\mathrm{ZrO}_{2}$ substrates vary with the coating thickness, as shown in Table 1 . The result suggests that the variations in the 


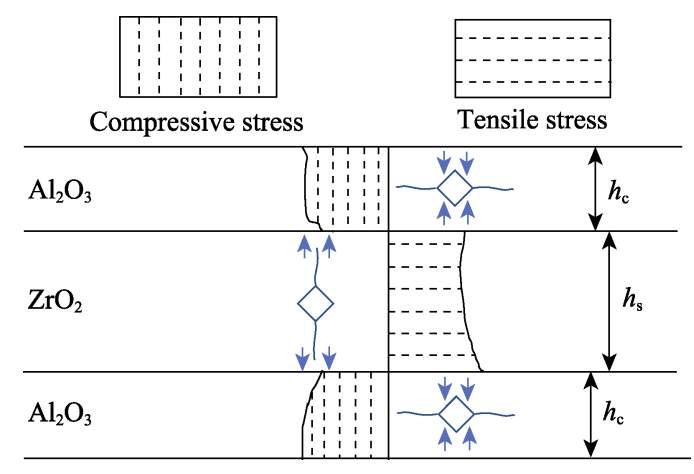

Fig. 4 Stress state and Vickers indentation of $A_{C} Z_{S}$ pre-stressed ceramics

$h_{\mathrm{s}}$ and $h_{\mathrm{c}}$ : the thicknesses of substrate and coating

length of crack is the consequences of varied residual stress in the $A_{C} Z_{S}$ pre-stressed ceramics with different values of $S_{\mathrm{s}} / S_{\mathrm{c}}$. Combined Eqs. (3) and (4), the residual stress in the $\mathrm{Al}_{2} \mathrm{O}_{3}$ coatings and $\mathrm{ZrO}_{2}$ substrates could be calculated.

$$
\sigma_{\mathrm{c}}=\left(\frac{S_{\mathrm{s}}}{S_{\mathrm{c}}}\right) \cdot\left\{1-\frac{\left[\frac{E_{\mathrm{s}} S_{\mathrm{s}}}{E_{\mathrm{c}} S_{\mathrm{c}}}+\frac{\alpha_{\mathrm{c}}}{\alpha_{\mathrm{s}}}\right]}{\left[1+\frac{E_{\mathrm{s}} S_{\mathrm{s}}}{E_{\mathrm{c}} S_{\mathrm{c}}}\right]}\right\} \cdot E_{\mathrm{s}} \cdot \alpha_{\mathrm{s}} \cdot \Delta T_{\mathrm{c}}
$$

In any cross-section of the sample, the tensile stresses in the substrate and the compressive stresses in the coating should keep balance,

$$
\sigma_{\mathrm{c}} S_{\mathrm{c}}=\sigma_{\mathrm{s}} S_{\mathrm{s}}
$$

where $S_{\mathrm{s},} E_{\mathrm{s}}, \alpha_{\mathrm{s}}$ are the values of the cross-section areas, elastic modulus and CTE of the substrate, $S_{\mathrm{c}}, E_{\mathrm{c}}$ and $\alpha_{\mathrm{c}}$ are those of the coating, respectively. $\Delta T$, the temperature difference, in this test: $\Delta T=T_{\text {sintering }}-T_{\text {room }}=1425{ }^{\circ} \mathrm{C}$.

Depending on the calculations, the values of residual stress in the coatings $\left(\sigma_{\mathrm{c}}\right)$ and substrates $\left(\sigma_{\mathrm{s}}\right)$ were plotted in Fig. 5. As is shown, $\sigma_{\mathrm{c}}$ increased while $\sigma_{\mathrm{s}}$ decreased with the value of $S_{\mathrm{s}} / S_{\mathrm{c}}$ increasing. It can be deduced that, with the value of $S_{\mathrm{s}} / S_{\mathrm{c}}$ increasing, the compressive stress in $\mathrm{Al}_{2} \mathrm{O}_{3}$ coatings increased, while the tensile stress in

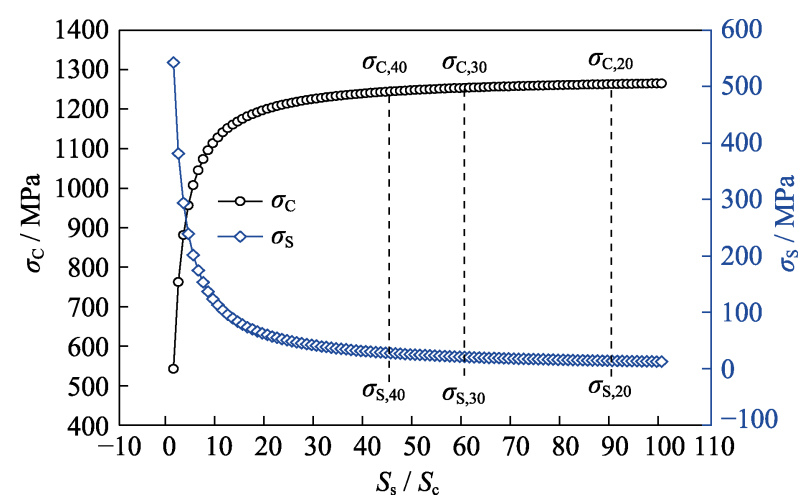

Fig. 5 Calculated residual stress in the $\mathrm{Al}_{2} \mathrm{O}_{3}$ coating and $\mathrm{ZrO}_{2}$ substrate of $A_{C} Z_{S}$ pre-stressed ceramics, as the function of the ratio of cross-sectional area of $\mathrm{ZrO}_{2}$ substrate to $\mathrm{Al}_{2} \mathrm{O}_{3}$ coating
$\mathrm{ZrO}_{2}$ substrates presented opposite tendency. As compressive stresses could restrain crack extension and the tensile stress could promote crack initiation and growth, the crack resistance of $\mathrm{A}_{\mathrm{C}} \mathrm{Z}_{\mathrm{S}}$ pre-stressed ceramics was enhanced as the value of $S_{\mathrm{s}} / S_{\mathrm{c}}$ increasing. This is consistent with the crack propagation behavior shown in Fig. 2(b) and Fig. 3.

Fractographic features of $\mathrm{ZrO}_{2}$ ceramics with and without $\mathrm{Al}_{2} \mathrm{O}_{3}$ coating (40 $\mu \mathrm{m}$ thick) were observed through SEM after bending tests. As shown in Fig. 6(a, c), the fracture morphology is smooth without ductile ridge marks. This means that the fracture mode of both $\mathrm{ZrO}_{2}$ ceramics and $\mathrm{A}_{\mathrm{C}} \mathrm{Z}_{\mathrm{S}}$ pre-stressed ceramics is brittle fracture. Grain sizes of uncoated $\mathrm{ZrO}_{2}$ ceramic and $\mathrm{ZrO}_{2}$ substrate of $A_{C} Z_{S}$ pre-stressed ceramics displayed in Fig. 6(b, d) are in the range of 400 to $600 \mathrm{~nm}$. Moreover, few pores can be found from the microstructure, indicating that the specimens prepared by the hot-pressing sintering method have high density.

The flexure strength of $A_{C} Z_{S}$ pre-stressed ceramics with $40 \mu \mathrm{m}$ thickness of $\mathrm{Al}_{2} \mathrm{O}_{3}$ coating is $(1207 \pm 20) \mathrm{MPa}$, which is $32 \%$ higher than that of $\mathrm{ZrO}_{2}$ ceramics $((821 \pm$ 15) $\mathrm{MPa}$ ) fabricated by the same process and about 3 -fold of the flexural strength of $\mathrm{Al}_{2} \mathrm{O}_{3}{ }^{[14]}$. According to the previous reports ${ }^{[15-17]}$, the $\mathrm{Al}_{2} \mathrm{O}_{3} / \mathrm{ZrO}_{2}$ composites fabricated by the conventional methods, such as ZTA or ATZ, or laminated $\mathrm{Al}_{2} \mathrm{O}_{3} / \mathrm{ZrO}_{2}$, mostly possess a strength with the value between those of $\mathrm{Al}_{2} \mathrm{O}_{3}$ and $\mathrm{ZrO}_{2}$. Generally, the strength of ceramic composites may be between the reinforcement material and matrix. However, the prestressing design endows the $\mathrm{A}_{\mathrm{C}} \mathrm{Z}_{\mathrm{S}}$ ceramics with a higher strength than $\mathrm{Al}_{2} \mathrm{O}_{3}$ and $\mathrm{ZrO}_{2}$. The results of the mechanical properties clearly show that the increase in strength is mainly attributed to the residual compressive stress in $\mathrm{Al}_{2} \mathrm{O}_{3}$ coating, thereby more energy was required for crack extension ${ }^{[18]}$. In addition, the robust interface between substrate and coating material also makes restrictions

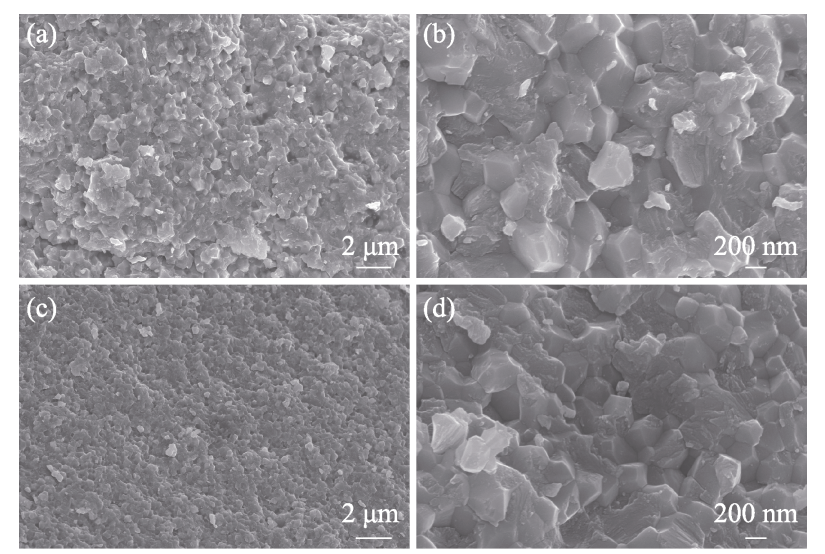

Fig. 6 SEM images of the fracture surfaces for monolithic $\mathrm{ZrO}_{2}$ ceramics $(a, b)$ and $\mathrm{ZrO}_{2}$ substrate of $\mathrm{A}_{\mathrm{C}} \mathrm{Z}_{\mathrm{S}}$ pre-stressed ceramics $(c, d)$ fabricated by the hot-pressing sintering method 
Table 1 Parameters used in formulas and the results of the experiment and simulation

\begin{tabular}{cccccccc}
\hline & & Elasticity modulus, $E / \mathrm{GPa}$ & $p / \mathrm{N}$ & $a / \mu \mathrm{m}$ & $c / \mu \mathrm{m}$ & $H_{\mathrm{V}} / \mathrm{GPa}$ & $K_{\mathrm{I}}, \mathrm{IFR} /\left(\mathrm{MPa} \cdot \mathrm{m}^{1 / 2}\right)$ \\
\hline $\mathrm{ZrO}_{2}$ & $\mathrm{ZrO}_{2}$ & 220 & 19.62 & 26.80 & 35.20 & 12.66 & 9.10 \\
\hline $\mathrm{A}_{\mathrm{C}} \mathrm{Z}_{\mathrm{S}}$ with & $\mathrm{Al}_{2} \mathrm{O}_{3}-40$ & 350 & 4.91 & 11.25 & 47.50 & 17.98 & 1.52 \\
$40 \mu \mathrm{m}$ coating & $\mathrm{ZrO}_{2}-40$ & 220 & 19.62 & 26.16 & 36.88 & 13.28 & 8.33 \\
\hline $\mathrm{A}_{\mathrm{C}} \mathrm{Z}_{\mathrm{S}}$ with & $\mathrm{Al}_{2} \mathrm{O}_{3}-30$ & 350 & 4.91 & 11.09 & 44.38 & 18.49 & 1.67 \\
$30 \mu \mathrm{m}$ coating & $\mathrm{ZrO}_{2}-30$ & 220 & 19.62 & 26.08 & 36.05 & 13.37 & 8.59 \\
\hline $\mathrm{A}_{\mathrm{C}} \mathrm{Z}_{\mathrm{S}}$ with & $\mathrm{Al}_{2} \mathrm{O}_{3}-20$ & 350 & 4.91 & 10.94 & 25.00 & 19.02 & 3.89 \\
$20 \mu \mathrm{m}$ coating & $\mathrm{ZrO}_{2}-20$ & 220 & 19.62 & 26.01 & 35.87 & 13.44 & 8.64 \\
\hline
\end{tabular}

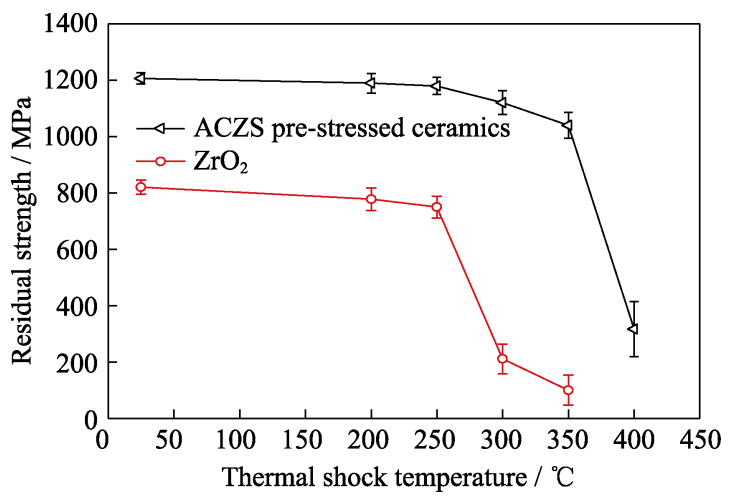

Fig. 7 Residual strength of $\mathrm{A}_{\mathrm{C}} \mathrm{Z}_{\mathrm{S}}$ pre-stressed ceramics and $\mathrm{ZrO}_{2}$ ceramics, after quenching at different thermal shock temperatures

against crack growth, which has a significant effect on the improvement of the strength and toughness ${ }^{[19]}$.

Another important mechanical property observed for ceramics is the damage tolerance, which represents the ability to inhibit crack extension. The residual strength of two materials was tested after thermal shock with various thermal shock temperatures, as illustrated in Fig. 7. The residual strength of both $\mathrm{ZrO}_{2}$ and $\mathrm{A}_{\mathrm{C}} \mathrm{Z}_{\mathrm{S}}$ pre-stressed ceramics with $40 \mu \mathrm{m}$ thickness $\mathrm{Al}_{2} \mathrm{O}_{3}$ coating were reduced with the quenching temperature increasing. Especially, the residual strength of $A_{C} Z_{S}$ pre-stressed ceramics rapidly dropped from $1040 \mathrm{MPa}$ to $317 \mathrm{MPa}$ when the thermal shock temperature raised from $350{ }^{\circ} \mathrm{C}$ to $400{ }^{\circ} \mathrm{C}$, while the residual strength of $\mathrm{ZrO}_{2}$ quenched at $350{ }^{\circ} \mathrm{C}$ was only $100 \mathrm{MPa}$. The result could be ascribed to that the compressive stresses existing in the coating layer can hinder the crack extension. Consequently, it is significant to introduce residual compressive stress in the surface layer of ceramic components to prevent crack propagation.

Owing to the high density and residual compressive stresses in the surface layer, $A_{C} Z_{S}$ pre-stressed ceramics were endowed with high flexural strength and excellent thermal shock resistance. Moreover, considering the feasibility in economy and simplification in the fabrication, the pre-stressing design to improve mechanical properties has great practical value and prospect in the fields of structural ceramics and domestic ceramics.
Besides, unlike the pre-stressed concrete and tempered glass, the pre-stressed ceramics can be machined to specific dimensions, which is more suitable for industrialized production.

\section{Conclusions}

Pre-stressing design was used to enhance the strength and damage tolerance of $\mathrm{ZrO}_{2}$ ceramics by coating a thin $\mathrm{Al}_{2} \mathrm{O}_{3}$ layer. The magnitude and direction of the residual stress were examined by Vickers indentation tests, and the crack resistance varied with the residual stress was further verified. Experiments indicated that the crack resistance of $A_{C} Z_{S}$ pre-stressed ceramics was enhanced with increasing ratio of the cross-sectional area of $\mathrm{ZrO}_{2}$ substrate to $\mathrm{Al}_{2} \mathrm{O}_{3}$ coating.

On account of the residual compressive stress in the coating, the bending strength of $\mathrm{ZrO}_{2}$ specimens coated with $40 \mu \mathrm{m}$ thickness of $\mathrm{Al}_{2} \mathrm{O}_{3}$ was $(1207 \pm 20) \mathrm{MPa}$ which is much higher than those of $\mathrm{ZrO}_{2}(850 \mathrm{MPa})$ and $\mathrm{Al}_{2} \mathrm{O}_{3}(400 \mathrm{MPa})$. After quenching from $350{ }^{\circ} \mathrm{C}$ to water, the residual strength of the $A_{C} Z_{S}$ pre-stressed ceramics was measured as $1040 \mathrm{MPa}$, while the measured residual strength of the $\mathrm{ZrO}_{2}$ was only $100 \mathrm{MPa}$.

\section{References:}

[1] DAHL P, KAUS I, ZHAO Z, et al. Densification and properties of zirconia prepared by three different sintering techniques. Ceramic International, 2007, 33(8): 1603-1610.

[2] MUKHOPADHYAY M, MUKHOPADHYAY J, SHARTNA A D, et al. High performance planar solid oxide fuel cell fabricated with Ni-yttria stabilized zirconia anode prepared by electroless technique. International Journal of Applied Ceramic Technology, 2012, 9(6): 999-1010.

[3] CHANG W G, SANG S H, JUN S H, et al. Investigation of stainless steel $316 \mathrm{~L} /$ zirconia joint part fabricated by powder injection molding. International Journal of Applied Ceramic Technology, 2019, 16(1): 315-323.

[4] ZHU T B, XIE Z P, HAN Y, et al. A novel approach to improve flexural strength of $\mathrm{Al}_{2} \mathrm{O}_{3}-20 \mathrm{wt} \% \mathrm{ZrO}_{2}$ composites by oscillatory pressure sintering. Journal of the American Ceramic Society, 2018, 101: 1397-1401.

[5] KARIHALOO B L. Contribution of $\mathrm{t} \rightarrow \mathrm{m}$ phase transformation to 
the toughening of ZTA. Journal of the American Ceramic Society, 1991, 74(7): 1703-1706.

[6] WANG X Z, MA Z L, SUN X, et al. Effects of $\mathrm{ZrO}_{2}$, and $\mathrm{Y}_{2} \mathrm{O}_{3}$, on physical and mechanical properties of ceramic bond and ceramic CBN composites. International Journal of Refractory Metals \& Hard Materials, 2018, 75: 18-24.

[7] BAO Y W, SU S B, YANG J J, et al. Pre-stressed ceramics and improvement of impact resistance. Materials Letters, 2002, 57: 518-524.

[8] BAO Y W, KUANG F H, SUN Y, et al. A simple way to make pre-stressed ceramics with high strength. Journal of Materiomics, 2019, 5: 657-662.

[9] BAO Y W, SUN Y, KUANG F H, et al. Development and prospects of high strength pre-stressed ceramics. Journal of Inorganic Materials, 2020, 35(4): 399-408.

[10] LI L, WAN L L, ZHOU Q M. Crack propagation during Vickers indentation of zirconia ceramics. Ceramics International, 2020, 46: 21311-21318.

[11] GREEN D J. Compressive surface strengthening of brittle materials by a residual stress distribution. Journal of the American Ceramic Society, 1983, 66(11): 807-810.

[12] HIROYUKI M, YOSHIZAWA Y. A reinvestigation of the validity of the indentation fracture (IF) method as applied to ceramics.
Journal of the European Ceramic Society, 2017, 37: 4437-4441.

[13] Test Method for Fracture Resistance of Silicon Nitride Materials for Rolling Bearing Balls at Room Temperature by Indentation Fracture (IF) Method. ISO 14627-2012, 2012-07.

[14] HAN Y, LI S, ZHU T B, et al. Enhanced properties of pure alumina ceramics by oscillatory pressure sintering. Ceramics International, 2018, 44(5): 5238-5241.

[15] DU W Y, AI Y L, HE W, et al. Formation and control of "intragranular" $\mathrm{ZrO}_{2}$ strengthened and toughened $\mathrm{Al}_{2} \mathrm{O}_{3}$ ceramics. Ceramics International, 2020, 46(6): 8452-8461.

[16] LI Y L, HYOUN-EE K, YOUNG-HAG K. Improving the surface hardness of zirconia toughened alumina (ZTA) composites by surface treatment with a boehmite sol. Ceramics International, 2012, 38(4): 2889-2892.

[17] TEBALDO V, GAUTIER G. Influences of evaluation methods and testing load on microhardness and Young's modulus of ZTA and ATZ ceramics. Ceramics International, 2013, 39(3): 2683-2693.

[18] YAO Y, ZHANG G F. Experimental study on pre-stress grinding process for alumina ceramic. Mining and Metallurgical Engineering, 2017, 37(2): 125-129.

[19] CHAUDHRI M M, CHEN L Y. The catastrophic failure of thermally tempered glass caused by small-particle impact. Nature, 1986, 320(6057): 48-50.

\title{
残余应力对涂覆 $\mathrm{Al}_{2} \mathrm{O}_{3}$ 涂层的 $\mathrm{ZrO}_{2}$ 陶瓷的 强度和裂纹扩展阻力的影响
}

\author{
李海燕 ${ }^{1,2}$, 郝鸿渐 ${ }^{1,2}$, 田 远 ${ }^{1,2}$, 汪长安 ${ }^{3}$, 包亦望 ${ }^{1,2}$, 万德田 ${ }^{1,2}$
}

(1. 中国建材检验认证集团股份有限公司，北京 $100024 ; 2$.中国建筑材料科学研究总院，绿色建材国家重点实验 室，北京 $100024 ; 3$. 清华大学 材料学院，新型陶瓷与精细工艺国家重点实验室，北京 100084)

摘 要: 本研究在 $\mathrm{ZrO}_{2}$ 基体表面涂覆一薄层 $\mathrm{Al}_{2} \mathrm{O}_{3}$ 涂层, 利用基体与涂层之间热膨胀系数不匹配, 在 $\mathrm{Al}_{2} \mathrm{O}_{3}-\mathrm{ZrO}_{2}$ 预 应力陶瓷(简称 $\mathrm{A}_{\mathrm{C}} \mathrm{Z}_{\mathrm{S}}$ 预应力陶瓷)表层引入压应力。采用维氏压痕法评价残余应力对 $\mathrm{A}_{\mathrm{C}} \mathrm{Z}_{\mathrm{S}}$ 预应力陶瓷的表层和基 体中裂纹扩展阻力的影响。理论分析结合实验结果表明: 表层的压应力使得 $\mathrm{A}_{\mathrm{C}} \mathrm{Z}_{\mathrm{S}}$ 预应力陶瓷的裂纹扩展阻力增大, 最终导致强度和损伤容限提高; 且 $\mathrm{A}_{\mathrm{C}} \mathrm{Z}_{\mathrm{S}}$ 预应力陶瓷表层的压应力和裂纹扩展阻力随着基体截面积与涂层截面积比 值的增加而增大。当 $\mathrm{ZrO}_{2}$ 基体表层的 $\mathrm{Al}_{2} \mathrm{O}_{3}$ 涂层厚度为 $40 \mu \mathrm{m}$ 时, 表层压应力使 $\mathrm{A}_{\mathrm{C}} \mathrm{Z}_{\mathrm{S}}$ 预应力陶瓷的弯曲强度达到 $(1207 \pm 20) \mathrm{MPa}$, 相比于同种工艺下制备的 $\mathrm{ZrO}_{2}$ 陶瓷强度提高了 $32 \%$, 同时也是 $\mathrm{Al}_{2} \mathrm{O}_{3}$ 强度的 3 倍。此外, $\mathrm{A}_{\mathrm{C}} \mathrm{Z}_{\mathrm{s}}$ 预 应力陶瓷也表现出很好的抗热震性能。

关 键 词: $\mathrm{Al}_{2} \mathrm{O}_{3}-\mathrm{ZrO}_{2}$ 预应力陶瓷; 压应力; 弯曲强度; 损伤容限

中图分类号: TQ174 文献标志码: A 